\title{
Interdependencies and telecoupling of oil palm expansion at the expense of Indonesian rainforest
}

\author{
Maria Cristina Rullia, *, Stefano Casirati, Jampel Dell'Angelo ${ }^{\mathrm{b}}$, Kyle Frankel Davis ${ }^{\mathrm{c}, \mathrm{d}, \mathrm{e}}$, Corrado Passera ${ }^{\mathrm{a}}$, \\ Paolo D'Odorico ${ }^{\mathrm{f}}$ \\ ${ }^{a}$ Department of Civil and Environmental Engineering, Politecnico di Milano, Piazza Leonardo da Vinci, 20131 Milan, Italy \\ ${ }^{\mathrm{b}}$ Department of Environmental Policy Analysis, Institute for Environmental Studies, VU University Amsterdam, Amsterdam, the Netherlands \\ ${ }^{c}$ Department of Geography, University of Delaware, Newark, DE 19716, USA \\ d Department of Plant and Soil Sciences, University of Delaware, Newark, DE 19716, USA \\ e Data Science Institute, Columbia University, New York, NY 10025 USA \\ ${ }^{\mathrm{f}}$ Department of Environmental Science, Policy, and Management, University of California, Berkeley, CA 94720, USA
}

\section{A R T I C L E I N F O}

\section{Keywords:}

Oil palm

Indonesia

Telecoupling

Rainforest

Deforestation

Fragmentation

Water scarcity, $\mathrm{CO} 2$ emissions

Globalization

Biofuel

\begin{abstract}
A B S T R A C T
Global palm oil production has greatly increased in recent years with the adoption of renewable energy policies by the E.U. and U.S.A. and growing demand for its use in food, biodiesel, and other commodities. Indonesia, the world's largest oil palm producer, has leased large tracts of forested and tribal lands as new concessions, thereby expanding oil palm plantations. While previous studies have focused on some of the important social and environmental consequences of this process, the full suite of potential environmental impacts from land conversion and cultivation remains poorly understood. Here we quantify these impacts in terms of forest loss and fragmentation, $\mathrm{CO}_{2}$ emissions from land use change, and freshwater pollution from fertilizer application. Within all concession types, forest cover decreased by $20 \%$ and forest fragmentation increased by $44 \%$, both of which are significantly higher than in comparable non-concession areas. We also assess to what extent $\mathrm{CO}_{2}$ emissions and freshwater pollution are attributable to increasing palm oil demand abroad. We find that four-fifths of Indonesia's palm oil production is for export markets and that $66 \%$ of this is destined for just eight countries - India, China, Pakistan, Malaysia, Italy, Egypt, Bangladesh, and the United Kingdom. Examining these multiple impacts highlights the importance of remote policies and consumption patterns in dictating local production decisions in a telecoupled world. This work demonstrates that - in order to be truly sustainable - bioenergy initiatives must ensure that adverse environmental impacts (and the demands that drive them) are reduced globally and not simply displaced elsewhere.
\end{abstract}

\section{Introduction}

Outputs of agricultural and forestry products from developing countries in tropical areas are increasing as a result of escalating global demands for food, fiber, and timber $([112,33,80]$. New international bioenergy and climate change mitigation policies play a key role in the expansion of frontiers of commercial agricultural production and drive rapid land use change $[114,119,25]$. Specifically, in the last decade, the European Union and the USA have enacted renewable energy policies that have promoted the use of biofuels for reducing anthropogenic $\mathrm{CO}_{2}$ emissions in an effort to combat climate change [122,41-43]. These policies have increased global demand for cropland, enhanced the profitability of land and agriculture investments, and produced distant linkages between consumer demand in one country and the environmental impacts of production in another $[58,67,92]$. Because of the growing prominence of international crop trade [105] [104,33,80,83], many of the investments for biofuel production in Southeast Asia are for the export market, with recent work estimating that $30-40 \%$ of biodiesel production relies on the importation of vegetable oil and feedstocks from foreign countries, mainly palm oil from Indonesia and Malaysia [108].

These distant interactions - where the impacts of policies of certain world regions extend well beyond their borders - raise fundamental challenges and opportunities for sustainable development [100]. Global issues such as land use change, biodiversity loss, food insecu-

\footnotetext{
* Corresponding author.

Email address: mariacristina.rulli@polimi.it (M.C. Rulli)
} 
rity, water scarcity, and deforestation are often the result of telecoupling between distant consumers and natural resources within the global, coupled human and natural system [23,36,38,39]. Globalization dynamics increase the levels of socio-environmental interdependency between remote geographical areas $[136,31,52,72,75]$. A remote cause triggered in a distant 'sending system' can produce strong impacts on 'receiving' and 'spillover' systems. Sending systems are the geographical site from which a certain flow of energy, matter, or information is sent while receiving systems are the destination of the flow. Spillover systems are not directly involved in the exchange but may still be affected by this interaction $[38,39]$. Complexity and world systems theories have been fundamental in demonstrating how unexpected outcomes are often produced through such global interactions [35,51,66,7].

Policies play a central role in determining the sustainability of these increasing international interdependencies. Paradoxically, those tailored for sustainability and environmental purposes have drawn the attention of scholarly research because of their frequent unintended consequences ( $t$ al. [63]; [115] [92] describe this phenomenon in the specific dimension of land use policies as a 'leakage' or 'indirect land use change' dynamic. The case of biofuels is one of the most important examples of leakage that is produced in a certain region by interventions to promote sustainable development in a distant foreign country. It has been argued that, through demand stimulation and imports, bioenergy policies in the EU and USA are causing radical land use change [91], deforestation [18], and large-scale land acquisitions [45]; et al., 2012) [114] in other regions of the world, particularly in Southeast Asia [26]. The unintended consequences of bioenergy policies in the EU and USA can cause cascading effects abroad such as water scarcity, water pollution, forest fragmentation, land degradation, or population displacement (e.g., [24];[82] , [112]; [34].

Oil palm plantations were introduced in Southeast Asia at the beginning of the 20th century, mainly in Malaysia and Indonesia, where their extent has increased with the decline of the rubber market. Together, these two countries account for 14 million hectares (ha) of oil palm plantations $[48,56,60]$ and $82 \%$ of global production [48]. Palm oil is used for the production of food, soap, cosmetics, and biofuel (about one third of the global biodiesel production [32] [108], with about half of it coming from Indonesia USDA-Global Agricultural Information Network [124]). Today, Indonesia is the largest grower of oil palm in the world, and its production is expected to continue to increase in the near future [99]. The country achieved this through rapid agricultural expansion over the last 15 years, $70 \%$ of which occurred at the expense of primary and secondary forests [99]. This phenomenon of sudden land conversion for oil palm threatens Indonesia's vast but dwindling rainforests in the world, particularly in West Kalimantan and Papua [18,61]. Moreover, recent work has shown that the $\mathrm{CO}_{2}$ emissions resulting from this land use change and the loss of belowground carbon stocks in peat forests will take several centuries to naturally recover and re-sequester (Fargione, 2008; [49]; [130].

Thus renewable energy policies [119] and rising international food [116] demand are having unintended detrimental environmental impacts in this country in the form of habitat loss [79], deforestation, and associated increases in carbon emissions [101,18,2,53,62], particularly in the case of peat forests [70],[94] a preferential target of palm oil investors (Fig. S1). The established nexus between Indonesian deforestation and E.U. bioenergy policies [2] has led the E.U. to revise its bioenergy policies to protect some ecosystems ( [43]; [63]. To avoid the negative environmental effects of bioenergy policies, the European Parliament has recently reached a provisional agreement on a revised renewable energy directive, imposing a 7\% cap on the use of first-generation biofuels with respect to the final consumption in the transport sector, and banning the use of palm oil by 2021 [44]. Data on biodiesel exports from Indonesia USDA-Global Agricultural Information Network
[125] show a decline in the last 2 years and an increase in domestic use in response to the biodiesel B20 blending mandate [95] (Ministerial Regulation No. 12/2015). During the same period other palm oil importers have increased their demand, thereby offsetting not only the EU decrease but also the effects of a recent (February 2018) 15\% increase in the tariffs on crude palm oil and refined palm oil products by the Indian government. While Indian imports of oil palm products have decreased by $35 \%$ between January and May 2018 compared with 2017, exports to Bangladesh, China, the US, and the Middle East have increased during the same period [125] . Therefore the overall trend of palm oil export from Indonesia continues to be positive [96]. This increasing demand for palm oil has also contributed to a surge in investments in large tracts of agricultural land in Indonesia [109]; [76]. The nexus between deforestation and large-scale land investments in Southeast Asia is only starting to be explored [26,34]. It remains unclear to what extent the increases in deforestation in the region are the outcome of growing demand for palm oil.

An extended literature on large-scale land acquisitions (LSLAs) and land grabbing has investigated the complex political economic dimensions of the contemporary land rush and the associated expansion of transnational land investments $[132,30,37,85]$. A variety of factors, often coexisting, have been identified by different scholars as the drivers of this global trend in LSLAs, such as: competitiveness of costs and financial speculation [3,91]; water resource availability [111,31,9]; anticipated climate change impacts [25]; the global energy transition [114]; development opportunities for commercial bioenergy production $[131,4,98]$; shifts in economic and geopolitical relations [22]; and market deregulation aimed at attracting foreign investments [29,137].

But what happens to forests? Do agribusiness investors preferentially acquire forested land under concession? Are these land concessions prone to deforestation for timber extraction, rubber production, or oil palm plantations? Indeed, while the extraction of forestry products is recognized as a major driver of forest loss (e.g., Runyan and D'Odorico, [112]), its connection with ongoing trends of globalization is often investigated in the context of international trade and associated land use displacement with no clear connection with ongoing trends in foreign land acquisitions [92]. With the exception of research on the impacts of LSLAs on deforestation in Cambodia [26], it is unclear whether foreign transnational large-scale land acquisitions are directly responsible for increased deforestation. Despite the relatively rich literature on "green grabbing" (i.e., land acquisitions for environmental ends [102], [45], [59], [107])), the relationship between increasing global demand for palm oil for bioenergy needs (as well as growing dietary demand (e.g., in China and India)) and deforestation produced by LSLAs still requires quantitative assessment.

Here we evaluate some of the environmental impacts associated with oil palm cultivation in Indonesia in the context of 'telecoupling' between distant actors and local natural resources. We analyze direct effects such as deforestation and land use change and cascading effects such as water scarcity, greenhouse gas emissions, and water pollution resulting from forest loss and oil palm production. Moreover, we analyze the global patterns of palm oil trade and the associated savings of grey water (i.e., avoided freshwater pollution from fertilizer runoff) and avoided $\mathrm{CO}_{2}$ emissions by importer countries.

\section{Methods}

\subsection{Datasets}

Data on the spatial extent of oil palm plantations and palm oil production in Indonesia were available at the province scale for the year 2015 through the Indonesian Palm Oil statistics [8] (BPS Indonesian Statistics https://www.bps.go.id/). Land concessions for oil palm plantation, logging, and fiber production (Table S1) were mapped by the 
Global Forest Watch (133) using data from the Ministry of the Forestry of the Indonesian Government. The spatial distribution of oil palm plantations was taken from the 2015 land cover map at $250 \mathrm{~m}$ spatial resolution [94]. Changes in forest cover (i.e., deforestation, reforestation/ afforestation, and fragmentation) within plantation areas were determined using annual forest cover maps (at $30 \times 30 \mathrm{~m}^{2}$ resolution, [61]), between 2000 and 2014. Year 2000 land cover data (at $250 \times 250 \mathrm{~m}^{2}$ resolution) were taken from Miettinen et al. [93].

To investigate the relationship between deforestation for oil palm and large-scale land acquisitions, we consider two main datasets: (a) forest cover maps (at $30 \times 30 \mathrm{~m}^{2}$ resolution developed by Hansen et al., [61], and (b) georeferenced data of land concessions for oil palm plantation, logging, and fiber production released by the Ministry of the Forestry of the Indonesian Government (133) (Fig. 1). Overlaying these two datasets allows us to determine the fraction of oil palm concession areas that were deforested between 2000 and 2014. Moreover deforestation was also determined for areas lying outside of land concession boundaries.

\subsection{Deforestation and fragmentation}

To examine whether and to what extent land concessions have enhanced forest loss and forest fragmentation in different areas across Indonesia, we analyzed changes in forest cover and forest fragmentation at the province scale. Forest cover and change in forest cover in the different types of concession and non-concession areas were analyzed using two indexes, namely forest cover index (FC) and change in forest cover index (CFC). FC is the fraction of the area (expressed as a percentage) covered by forest with respect to the entire area. CFC describes the increase/decrease of forest cover in the time interval 2000-2014. Fragmentation analyses were carried out following the approach by Vogt et al. [128] who used binary land cover maps to define 4 land cover types: forest cores, patches, edges, and perforated areas (Fig. S2). First the landscape was subdivided into a square lattice of $30 \times 30 \mathrm{~m}^{2}$ pixels. We then classified each pixel as wooded or non-wooded. Wooded pixels had an initial (year 2000) forest cover greater than $50 \%$ (where Hansen et al. [61] define tree cover as any vegetation taller than $5 \mathrm{~m}$ ). For any forested pixels where forest loss was reported in one of the study years, we assumed complete forest cover loss (i.e., $0 \%$ forest cover) for the remainder of the study period. Forest cores were defined as wooded pixels that are not adjacent to non-wooded pixels. Forest patches were wooded pixels that are not adjacent to forest core pixels. Forest margins were wooded pixel that were neither core nor patch pixels. Margins were named forest edges if they were placed along the forest core perimeter adjacent to non-forest core pixels; perforated areas are adjacent to smaller non-wooded areas (Fig. S2). In our analysis we considered a threshold of $100 \mathrm{~m}$ to distinguish perforated from edge areas [128].

We used a composite fragmentation index (CFI) [110] to describe forest fragmentation in our study area. CFI is defined as the ratio between the sum of number of pixels classified as "edges", "perforated", "patches", or smaller core areas (i.e., < 200 ha), and the total number of pixels (wooded + non-wooded) in that area (which corresponded to the extent of a given province). CFI varies between 0 and 1 , where CFI approaches 1 in areas with extremely fragmented forest cover, and is equal to 0 in areas with no fragmented forest cores or no forest cover at all. We analyzed CFI in the years 2000 and 2014 and calculated the change in CFI (CCFI) during the interval 2000-2014.

Differences in FC, CFC, CFI, and CCFI values between concession and non-concession areas were tested for significance with a Mann-Whitney $U$-test [110]. To this end, 500 random circles having a $25 \mathrm{~km}$ diameter were randomly scattered across Indonesia's land area and
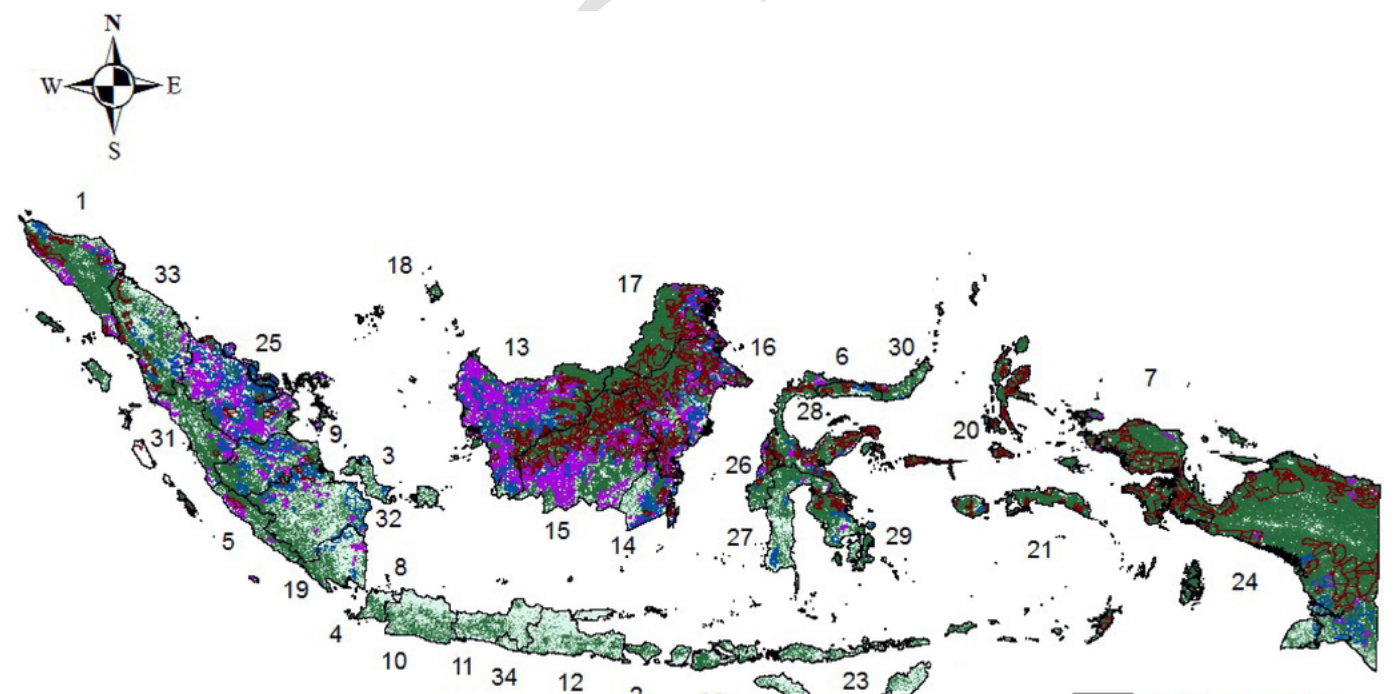

22

Indonesia provinces

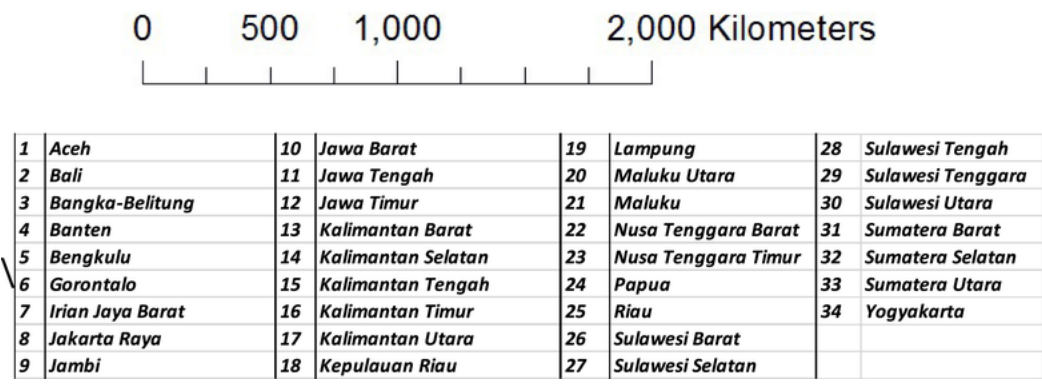

Logging Concessions

Fiber Concessions OilPalm Concessions

Fig. 1. Map of concessions for logging, fibers and oil palm across Indonesia. 
then classified depending on their position considering a buffer area of $5 \mathrm{~km}$ around any type of concession (random circles falling in areas where different type of concessions are overlapped were not considered). Thus 4 categories of random circles were considered, namely random circles in oil palm concessions, in logging concessions, in fiber concessions and in non-concession areas. Statistical analyses were carried out both considering all concessions together and one by one. The biases associated with the higher population density in the proximity to land concessions were eliminated by performing the same test on a subset $(\sim 300$ random circles) of the 500 randomly distributed circles with population density comprised within the interquartile range (IQR) of the population inside land concessions. This was done after verifying that the population density in the circles inside land concessions was not significantly different ( $\mathrm{p}$-value $>0.76$ ) from that in these 300 IQR areas.

\subsection{Water scarcity}

Monthly blue water scarcity (WS) was calculated within 10' grid cells as the ratio of the local blue water footprint $\left(\mathrm{WF}_{\text {loc }}\right)$ (i.e., consumptive irrigation water demand) to the total blue water availability $\left(\mathrm{WA}_{\text {tot }}\right)$ for that month after accounting for environmental flows (89:

$$
\mathrm{WS}=\frac{\mathrm{WF}_{\text {loc }}}{\mathrm{WF}_{\mathrm{tot}}}
$$

Following Mekonnen and Hoekstra [89], blue water scarcity values were classified into four ranges: low (WS $<1.0)$, moderate $(1.0<$ WS $<1.5$ ), significant $(1.5<$ WS $<2.0$ ), and severe (WS $>2.0)$. A WS value of 1 means that the available sustainable blue water has been fully consumed; at WS > 1.0, environmental flow requirements are not met. $\mathrm{WF}_{\text {loc }}$ was calculated as the sum of the blue water footprint for agriculture, industrial production, and municipal uses. The agricultural water footprint was based on average values for the 10-year period 1996-2005 using the spatially distributed version of the CROPWAT model [46] . Data on the blue water footprints of the industrial and municipal sectors were taken from Mekonnen and Hoekstra [87]. $\mathrm{WA}_{\text {tot }}$ in each grid cell was obtained by summing the $\mathrm{WA}_{\mathrm{loc}}$ and the net blue water from upstream cells (i.e., the runoff generated in upstream cells $\left(\mathrm{WF}_{\mathrm{up}}\right)$ minus the local blue water footprint in these cells).

Monthly $\mathrm{WA}_{\text {loc }}$ values were calculated by subtracting the environmental flow requirement from the natural runoff. Natural runoff per grid cell was calculated by summing the actual runoff and the blue water footprint within the grid cell. Runoff was calculated by Fekete et al., [50] at the monthly time scale at $10 \times 10^{\prime}$ resolution. Environmental flows were assumed to be equal to $80 \%$ of the natural runoff [106].

\section{4. $\mathrm{CO}_{2}$ emissions}

We estimated gross carbon dioxide emissions from forest loss in Indonesia following Abood et al. [1]. The emission factors for deforestation and peat degradation were calculated based on data on biomass, nonpeat soil, and peat soil. Carbon emissions from deforestation were considered to be associated with the carbon contained in the aboveground (AGB) and belowground (BGB) biomass [5] and a below-to-aboveground biomass ratio of 0.18 was used to estimate BGB biomass [57]. Following Abood et al. [1] we considered both emissions for AGB estimates for intact forests and for disturbed forests (where the biomass loss was considered to be equal to $60 \%$ [16]- [19]). Carbon sequestered through plantation growth was not considered [13,14]. $\mathrm{CO}_{2}$ emissions from deforestation in areas with non-peat soil were assumed to lose $10 \%$ of their soil carbon content in the top $30 \mathrm{~cm}$ FAO/IIASA/ISRIC/ISS-CAS/JRC [47]. We calculated carbon emissions from peat soils in burning and non-burning conditions ([65] al., [19].
Land cover classification data for Indonesia for the year 2000 was based on Miettinen et al. [93]. We calculated forest loss during 2000-2014 for every province and for each type of forest existing in oil palm concessions and in oil palm plantations in the year 2000 (i.e. lowland forest, peat swamp forest, lower montane forest, upper montane forest, mangrove). Above-ground biomass estimates for the different land cover classes were taken from the literature as follows: 20.2 $\mathrm{Mg} \mathrm{C} \mathrm{ha}^{-1}$ in upper montane forests (assuming the same values for all provinces [69]); $229 \mathrm{Mg} \mathrm{Cha}^{-1}$ for intact lowland forests and 91.6 $\mathrm{Mg} \mathrm{Cha}{ }^{-1}$ for disturbed forests in Kalimantan [120]; $360.4 \mathrm{Mg} \mathrm{Cha}{ }^{-1}$ for intact forests and $144.2 \mathrm{Mg} \mathrm{Cha}^{-1}$ for disturbed forests in Sumatra [73]; 152.2 $\mathrm{Mg} \mathrm{Cha}^{-1}$ for intact forests and $81.8 \mathrm{Mg} \mathrm{Cha}^{-1}$ for disturbed forests in Papua and $175 \mathrm{Mg} \mathrm{Cha}^{-1}$ for intact forests and 70.3 $\mathrm{Mg} \mathrm{Cha}{ }^{-1}$ for disturbed forests in Moluku [1]; . Because there are only limited AGB estimates for mangroves, peat swamp forests, and lowland montane forests in Indonesia, we used country-level estimates for mangrove (104.9 $\mathrm{Mg} \mathrm{Cha}^{-1}$ ) (Donato et al., 2011), peat swamp forest (179.9 $\mathrm{Mg} \mathrm{C} \mathrm{ha}^{-1}$ ) (Murdiyarso et al., 2010), and lowland montane forest (380.8 $\mathrm{Mg}$ ) [69]. Moreover, because AGB estimates were not available for certain province-land cover class combinations, we used average AGB estimates for each land cover class calculated on the provinces where AGB was known.

According to Abood et al. [1], carbon dioxide emissions from deforestation were calculated under two scenarios representing the minimum and the maximum magnitude of emissions. In the first scenario we considered disturbed forests in all lowlands and no peatlands burning, while in the second scenario we assumed intact forests and burned peatlands.

\subsection{Pollution due to oil palm fertilization}

Oil palm production typically requires the use of nitrogen fertilizers $[71][81,88]$, and the associated release of reactive nitrogen to the environment can have cascading effects on environmental nutrient cycling [55] with important implications for the functioning of natural systems. The impacts of oil palm fertilization on water quality were evaluated in terms of grey water footprint (GWF), defined as the volume of water necessary to dilute the concentration of pollutants (in this case nitrates) in streams and groundwater below existing quality standards. Thus, GWF depends on fertilizer application rates, background nitrate levels, and acceptable quality standards (here assumed to be $10 \mathrm{mg}$ $\mathrm{NO}_{3}{ }^{-} \mathrm{N}$ per liter of water, based on the policies adopted by the Environmental Protection Agency in the USA [88]). Therefore GWF was expressed [88] as:

$$
G W F=\frac{L_{n}}{\left(c_{\max }-c_{\text {nat }}\right)}\left[\frac{\text { volume }}{\text { area } \bullet \text { time }}\right]
$$

by dividing the load of nitrogen $\left(L_{n}\right)$ entering the freshwater system by the difference between the maximum allowable concentration $\left(c_{\max }\right)$ and the natural background concentration of nitrogen in the water body $\left(c_{n a t}\right) . \mathrm{L}_{\mathrm{n}}$ is calculated by multiplying the average application rate of fertilizer and the average leaching runoff fraction here set equal to 0.1 as in Chapagain et al. [20]. Because data on fertilizer use per unit area were not available by province, we assumed the same application rate of fertilizer in every province. Fertilizer application rates on peatland soils in Indonesia (mostly histosols) were set equal to $1 \mathrm{~kg} \mathrm{~N}^{\mathrm{palm}} \mathrm{y}^{-1}$ [81]. Considering a typical oil palm density of 148 palm ha $^{-1}$, the average $\mathrm{N}$ application rate was $148 \mathrm{~kg} \mathrm{~N} \mathrm{ha}^{-1} \mathrm{y}^{-1}$ [81] . In the case of oil palm planted in areas with no peat, the application rate set at $166.5 \mathrm{~kg} \mathrm{~N} \mathrm{ha}^{-1}$ $\mathrm{y}^{-1}$ Von Uexkull and Fairhurst [129], corresponding to $1.12 \mathrm{~kg} \mathrm{~N}$ palm $^{-1}$ $\mathrm{y}^{-1}$ (mean between 0.90 and 1.35) ([129]). These application rates agree both with values reported by Van Noordwijk et al., [127] (who calculated an average fertilizer application rate of $141 \mathrm{~kg} \mathrm{~N} \mathrm{ha}^{-1} \mathrm{yr}^{-1}$ across 23 plantations) and with values reported by Wot- 
tiez et al. [134] for smallholder plantations in Sintang, Indonesia. Different average application rates of $95 \mathrm{~kg} \mathrm{~N} \mathrm{ha}^{-1} \mathrm{yr}^{-1}$ were used by Bulsink et al. (2010) [11] for Indonesia provinces and by Wottiez et al. [134] for Jambi. Here GWF was evaluated taking into account the current oil palm plantations as well as the establishment of oil palm plantations in all oil palm concessions referring both to a average application rates of $95 \mathrm{~kg} \mathrm{~N} \mathrm{ha}^{-1} \mathrm{yr}^{-1}$ and 148 and $166.5 \mathrm{~kg} \mathrm{~N} \mathrm{ha}^{-1} \mathrm{y}^{-1}$ on peatland and no peatland soils, respectively.

\section{Results}

\subsection{Forest loss and fragmentation}

Our spatial analysis of land use change in Indonesia after the year 2000 shows that more than 20 million hectares (ha) have been deforested (Fig. 2, Table S2). Target regions for this land use change are (not surprisingly) concentrated in the Kalimantan and Sumatra islands (Table 1, S2). When compared with areas with statistically similar population density outside land concessions, concession areas had a higher than average forest cover in 2000 and were affected by higher than average rates of forest loss between 2000 and 2014, particularly in the Kalimantan (Table 1). In the year 2000, forest cover outside of concession areas was about $66 \%$, while initial forest cover in oil palm, logging, and fiber concessions lands was $73 \%, 93 \%$, and $78 \%$, respectively. The year 2014 in particular saw a sharp decrease in forest cover within concession areas. Concessions for oil palm plantations played a crucial role in land use change in Indonesia, containing $8 \%$ of total initial forested area of the country but accounting for $22 \%$ of the areas affected by deforestation. Both total deforestation and deforestation in concessions for oil palm has increased since the year 2000 (Fig. 2; Table S2). We estimate that approximately $30 \%$ of this forest loss (i.e., $\sim 5.8$ million ha) is attributable to oil palm plantations and $21 \%$ of forest loss (i.e., $\sim 4.25$ million ha) has taken place within oil palm concessions (Table S2).

Similar to patterns of forest loss, land concessions were preferentially affected by an increase in forest fragmentation. The analysis of forest fragmentation showed that in the year 2000 the composite fragmentation index (CFI) in concession areas was on average lower (0.19) than the CFI in non-concession areas (0.21). When comparing different concessions types, logging concessions forests were less fragmented (CFI $=0.09$ ) in year 2000 , while oil palm and fiber concessions were more fragmented (CFI equal to 0.26 and 0.22 respectively) (Table 2).

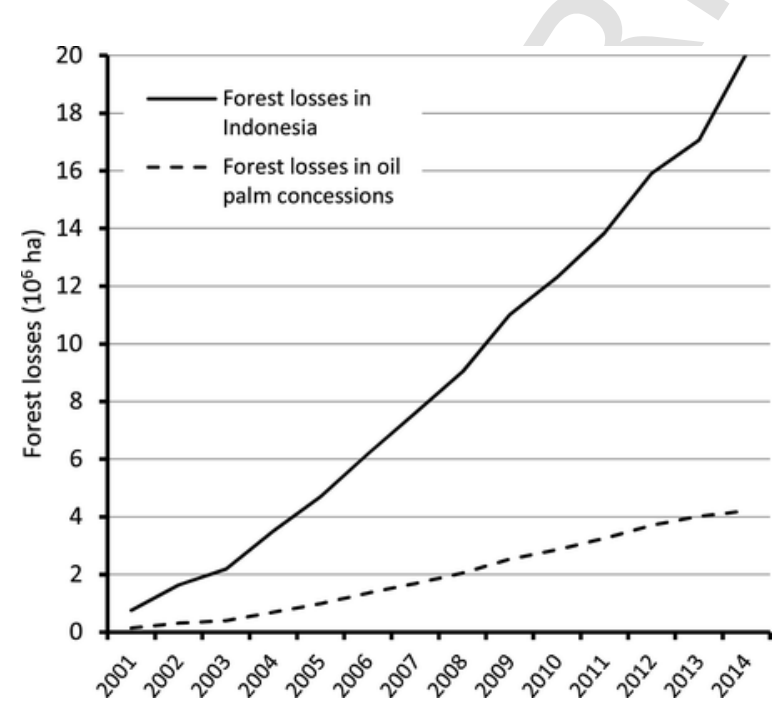

Fig. 2. Contribution of oil palm concessions to land use change in Indonesia (2000-2014).
The most fragmented forests in oil palm concessions in year 2014 were found in the provinces of Sulawesi Barat, Kepulauan Riau, and Kalimantan Barat (Table 2). Fragmentation within fiber concessions showed the highest values in the provinces of Bengkulu and Sulawesi Utara. Over the study period, the development of a large number of concessions led to a $44 \%$ increase in CFI (CCFI) in concessions areas. In 2014 oil palm, logging, and fiber concessions exhibited a CFI value $(0.34 ; 0.35$ and 0.17 respectively) significantly higher (p-value « 0.001 ) than areas with comparable population density outside concession areas $(\mathrm{CFI}=0.18$ ). The highest increase in CFI (CCFI) was experienced in logging concessions $(+109 \%)$, followed by those for fiber $(+96 \%)$ and oil palm $(+27 \%)$. Forest fragmentation due to oil palm plantations increased most markedly in the provinces of Sulawesi Utara and Irian Jaya Barat (CCFI of $270 \%$ and $115 \%$ respectively). Logging concessions most enhanced fragmentation in Bengkulu and Sulawesi Barat provinces (CCFI of $234 \%$ and $217 \%$ respectively) while fiber concessions strongly increased fragmentation in Bengkulu and Sulawesi Utara provinces (CCFI of $1350 \%$ and $362 \%$ respectively). The change in CFI (CCFI) between 2000 and 2014 was significantly higher in oil palm concessions than in non-concession areas (p-value « 0.001).

\subsection{Other environmental impacts: water pollution and $\mathrm{CO}_{2}$ emissions}

The impact of oil palm plantations on Indonesia's water resources is more pronounced during Indonesia's dry season ( June-September), when the irrigation demands of permanent oil palm plantations are more likely to induce conditions of water scarcity. Our analysis (Fig. 3) shows that during these months the rate of water demand for agriculture and other uses exceeds the rate of water availability in certain locations, potentially leading to seasonal groundwater depletion and insufficient environmental flows. We also find that the expansion of oil palm cultivation has also meant that the areal extent of seasonal water scarcity has also grown.

In addition to the potentially unsustainable water demands of oil palm production, we quantified the associated $\mathrm{CO}_{2}$ emissions (due to deforestation) and nutrient runoff (due to fertilizer application) associated with oil palm plantations and concessions (Table S2). We found out that oil palm plantations are responsible for a net carbon loss of 2.43-4.37 Gt at the country scale. A large portion (about 22\%) of oil palm plantation area lies over peatlands, where large carbon stocks occur and where $\mathrm{CO}_{2}$ emission rates due to deforestation tend to be much higher. The highest $\mathrm{CO}_{2}$ emissions occur in Kalimantan Tengah. In addition, large expanses of land concessions for oil palm plantations are not yet cultivated but have already been deforested, thereby inducing $\mathrm{CO}_{2}$ emissions.

Regarding fertilizer use, the provinces with the largest grey water footprints (i.e., the volume of water required to dilute nitrates from fertilizer runoff to an acceptable concentration) were Riau, Sumatera Utara, Kalimantan Tangah, and Kalimantan Barat (Table S2). Presently about $70 \%$ of oil palm concessions are not yet cultivated, and about $20 \%$ of these uncultivated oil palm concessions are on peatlands, which suggests that the environmental effects due to oil palm cultivation are likely to continue mounting in the future.

\subsection{Virtual pollution exports due to palm oil trade}

Lastly, we analyzed the virtual export of pollution from importing countries to Indonesia by considering the embodied $\mathrm{CO}_{2}$ emissions and grey water footprints of palm oil importer countries (Table S3). Currently (as of the year 2015), 26 million tonnes of crude palm oil (CPO) are exported internationally from Indonesia, the production of which was supported by substantial $\mathrm{CO}_{2}$ emissions (2.43-4.37 Gt tonnes $\mathrm{CO}_{2} \mathrm{eq}$ ) and synthetic fertilizer runoff $\left(13 \mathrm{~km}^{3}\right.$ grey $\left.\mathrm{H}_{2} \mathrm{O}\right)$ (Figs. 4 and 5 , Table S3). CPO trade occurs mainly among Asian countries with India, 
Table 1

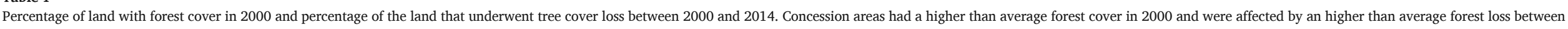
2000 and 2014. The geographic distribution of the provinces is shown in Fig. 1.

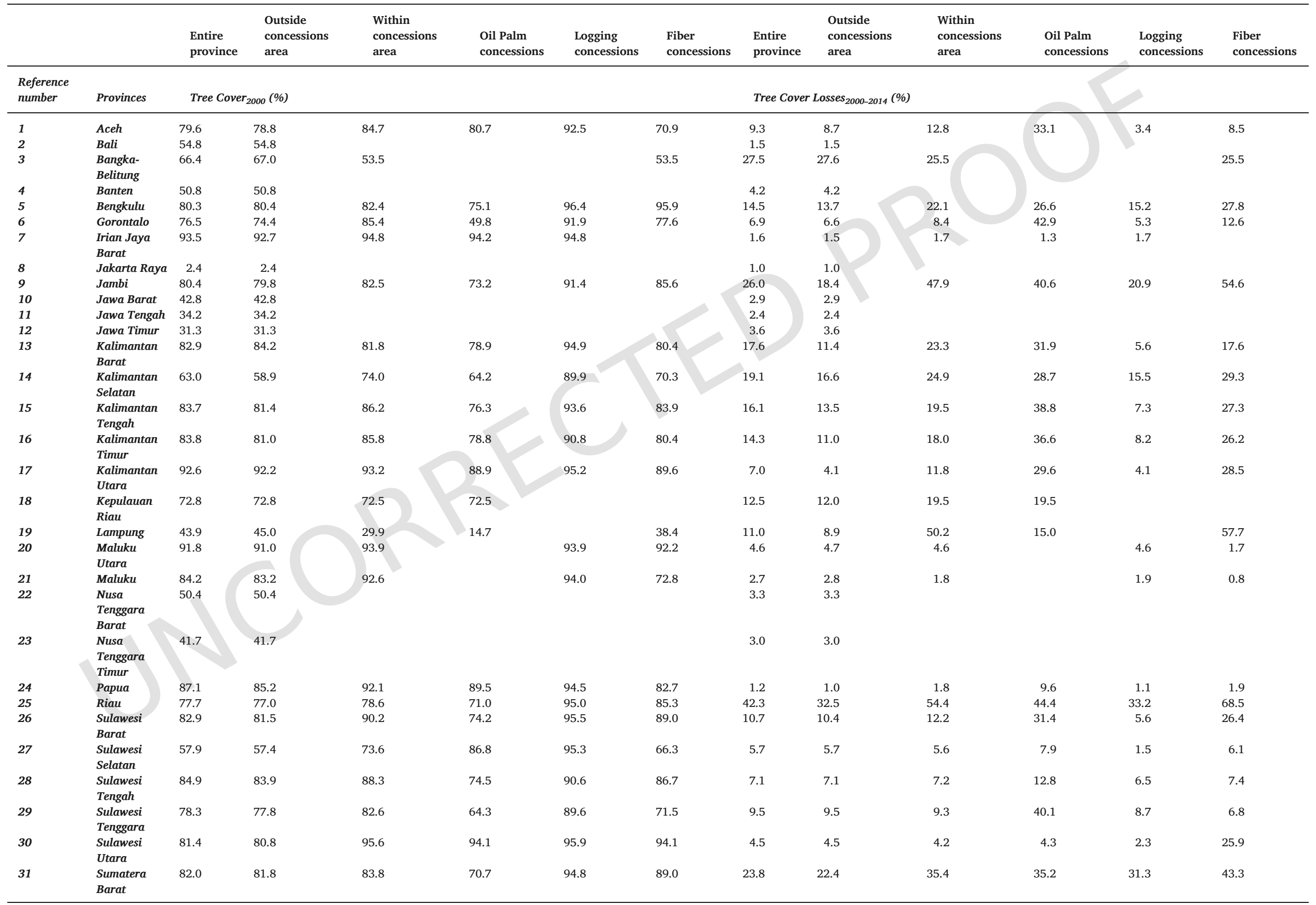


Table 1 (Continued)

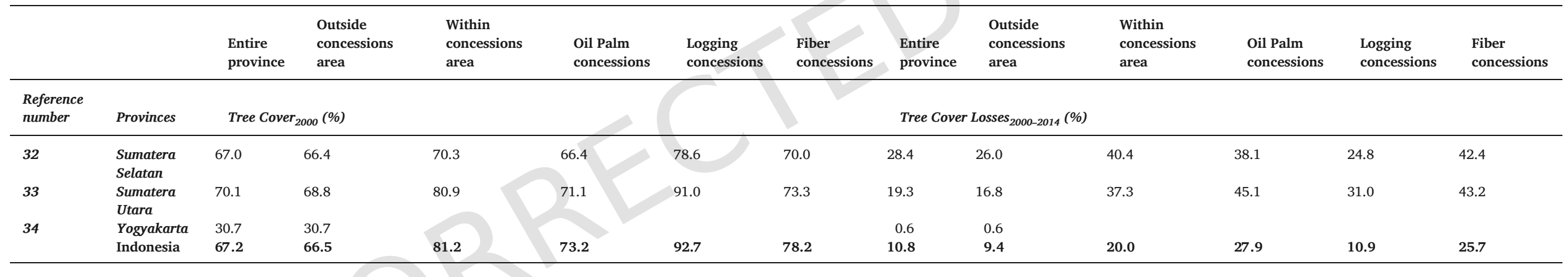


Table 2

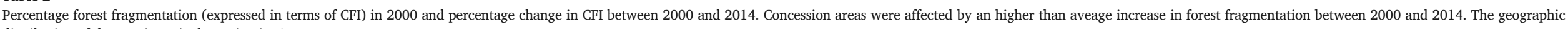
distribution of the provinces is shown in Fig. 1.

\begin{tabular}{|c|c|c|c|c|c|c|c|c|c|c|c|c|c|}
\hline & & $\begin{array}{l}\text { Entire } \\
\text { province }\end{array}$ & $\begin{array}{l}\text { Outside } \\
\text { concessions } \\
\text { area }\end{array}$ & $\begin{array}{l}\text { Within } \\
\text { concessions } \\
\text { area }\end{array}$ & $\begin{array}{l}\text { Oil Palm } \\
\text { concessions }\end{array}$ & $\begin{array}{l}\text { Logging } \\
\text { concessions }\end{array}$ & $\begin{array}{l}\text { Fiber } \\
\text { concessions }\end{array}$ & $\begin{array}{l}\text { Entire } \\
\text { province }\end{array}$ & $\begin{array}{l}\text { Outside } \\
\text { concessions } \\
\text { area }\end{array}$ & $\begin{array}{l}\text { Within } \\
\text { concessions } \\
\text { area }\end{array}$ & $\begin{array}{l}\text { Oil Palm } \\
\text { concessions }\end{array}$ & $\begin{array}{l}\text { Logging } \\
\text { concessions }\end{array}$ & $\begin{array}{l}\text { Fiber } \\
\text { concessions }\end{array}$ \\
\hline $\begin{array}{l}\text { Reference } \\
\text { number }\end{array}$ & Provinces & $C F I_{2000}(-)$ & & & \multicolumn{9}{|c|}{ Change in $\mathrm{CFI}_{2000-2014}(\%)$} \\
\hline 1 & Aceh & 0.16 & 0.16 & 0.17 & 0.30 & 0.07 & 0.23 & 25.70 & 24.99 & 30.21 & 22.43 & 65.47 & 17.52 \\
\hline 2 & Bali & 0.28 & 0.28 & & & & & 10.19 & 10.19 & & & & \\
\hline 3 & $\begin{array}{l}\text { Bangka- } \\
\text { Belitung }\end{array}$ & 0.44 & 0.44 & 0.42 & & & 0.42 & -13.21 & -12.92 & -20.34 & & & -20.34 \\
\hline 4 & Banten & 0.31 & 0.31 & & & & & 6.26 & 6.26 & & & & \\
\hline 5 & Bengkulu & 0.27 & 0.27 & 0.19 & 0.26 & 0.05 & 0.03 & 29.65 & 28.86 & 50.16 & 32.09 & 233.63 & 1350.00 \\
\hline 6 & Gorontalo & 0.15 & 0.15 & 0.12 & 0.16 & 0.08 & 0.19 & 13.23 & 6.45 & 47.87 & -1.41 & 59.58 & 42.85 \\
\hline 7 & $\begin{array}{l}\text { Irian Jaya } \\
\text { Barat }\end{array}$ & 0.07 & 0.07 & 0.06 & 0.06 & 0.06 & & 81.39 & 64.74 & 114.76 & 115.23 & 114.75 & \\
\hline 8 & Jakarta Raya & 0.01 & 0.01 & & & & & -3.12 & -3.12 & & & & \\
\hline 9 & Jambi & 0.27 & 0.27 & 0.31 & 0.42 & 0.13 & 0.28 & 27.19 & 35.57 & 3.57 & -8.65 & 105.22 & 5.82 \\
\hline 10 & Jawa Barat & 0.28 & 0.28 & & & & & 1.36 & 1.36 & & & & \\
\hline 11 & Jawa Tengah & 0.22 & 0.22 & & & & & 0.60 & 0.60 & & & & \\
\hline 12 & Jawa Timur & 0.15 & 0.15 & & & & & 7.77 & 7.77 & & & & \\
\hline 13 & $\begin{array}{l}\text { Kalimantan } \\
\text { Barat }\end{array}$ & 0.24 & 0.19 & 0.28 & 0.34 & 0.07 & 0.28 & 34.12 & 41.00 & 29.86 & 19.22 & 142.51 & 40.94 \\
\hline 14 & $\begin{array}{l}\text { Kalimantan } \\
\text { Selatan }\end{array}$ & 0.25 & 0.25 & 0.25 & 0.30 & 0.16 & 0.28 & 9.24 & 4.66 & 20.96 & 7.22 & 75.86 & 11.74 \\
\hline 15 & $\begin{array}{l}\text { Kalimantan } \\
\text { Tengah }\end{array}$ & 0.18 & 0.19 & 0.16 & 0.26 & 0.09 & 0.23 & 38.38 & 32.37 & 47.17 & 4.01 & 146.70 & 18.39 \\
\hline 16 & $\begin{array}{l}\text { Kalimantan } \\
\text { Timur }\end{array}$ & 0.20 & 0.19 & 0.21 & 0.27 & 0.15 & 0.32 & 25.96 & 15.51 & 33.15 & 12.28 & 66.53 & 12.20 \\
\hline 17 & $\begin{array}{l}\text { Kalimantan } \\
\text { Utara }\end{array}$ & 0.07 & 0.06 & 0.09 & 0.15 & 0.06 & 0.18 & 65.05 & 40.19 & 91.94 & 57.61 & 134.08 & 62.67 \\
\hline 18 & $\begin{array}{l}\text { Kepulauan } \\
\text { Riau }\end{array}$ & 0.31 & 0.31 & 0.38 & 0.38 & & & 22.20 & 22.24 & 21.60 & 21.60 & & \\
\hline 19 & Lampung & 0.24 & 0.24 & 0.20 & 0.08 & & 0.26 & 3.52 & 6.97 & -49.32 & -13.59 & & -55.74 \\
\hline 20 & $\begin{array}{l}\text { Maluku } \\
\text { Utara }\end{array}$ & 0.12 & 0.13 & 0.10 & & 0.10 & 0.10 & 125.61 & 116.76 & 156.66 & & 156.89 & 140.78 \\
\hline 21 & Maluku & 0.16 & 0.17 & 0.08 & & 0.07 & 0.24 & 41.56 & 38.29 & 98.26 & & 117.60 & 16.36 \\
\hline 22 & $\begin{array}{l}\text { Nusa } \\
\text { Tenggara } \\
\text { Barat }\end{array}$ & 0.15 & 0.15 & & & & & 12.88 & 12.88 & & & & \\
\hline 23 & $\begin{array}{l}\text { Nusa } \\
\text { Tenggara } \\
\text { Timur }\end{array}$ & 0.22 & 0.22 & & & & & 3.85 & 3.85 & & & & \\
\hline 24 & Рариа & 0.11 & 0.12 & 0.08 & 0.12 & 0.06 & 0.15 & 29.78 & 23.91 & 52.46 & 30.47 & 82.01 & 13.00 \\
\hline 25 & Riau & 0.24 & 0.25 & 0.23 & 0.30 & 0.05 & 0.17 & 1.09 & 10.07 & -10.61 & -7.98 & 130.23 & -23.44 \\
\hline 26 & $\begin{array}{l}\text { Sulawesi } \\
\text { Barat }\end{array}$ & 0.24 & 0.25 & 0.17 & 0.55 & 0.04 & 0.21 & 30.64 & 29.87 & 36.91 & -14.64 & 216.66 & 79.15 \\
\hline 27 & $\begin{array}{l}\text { Sulawesi } \\
\text { Selatan }\end{array}$ & 0.23 & 0.23 & 0.28 & 0.15 & 0.05 & 0.35 & 5.90 & 5.74 & 10.19 & 60.96 & 119.81 & 2.11 \\
\hline 28 & $\begin{array}{l}\text { Sulawesi } \\
\text { Tengah }\end{array}$ & 0.18 & 0.19 & 0.14 & 0.22 & 0.12 & 0.16 & 49.48 & 46.38 & 65.15 & 32.06 & 77.44 & 44.59 \\
\hline 29 & $\begin{array}{l}\text { Sulawesi } \\
\text { Tenggara }\end{array}$ & 0.20 & 0.22 & 0.11 & 0.42 & 0.10 & 0.09 & 18.85 & 18.18 & 28.35 & -16.08 & 35.27 & 41.72 \\
\hline 30 & $\begin{array}{l}\text { Sulawesi } \\
\text { Utara }\end{array}$ & 0.27 & 0.28 & 0.04 & 0.06 & 0.03 & 0.09 & 35.09 & 33.93 & 221.68 & 270.12 & 173.92 & 362.40 \\
\hline 31 & $\begin{array}{l}\text { Sumatera } \\
\text { Barat }\end{array}$ & 0.18 & 0.18 & 0.18 & 0.30 & 0.08 & 0.15 & 28.68 & 28.19 & 32.02 & 2.98 & 98.88 & 79.47 \\
\hline
\end{tabular}


Table 2 (Continued)

\begin{tabular}{|c|c|c|c|c|c|c|c|c|c|c|c|c|c|}
\hline & & $\begin{array}{l}\text { Entire } \\
\text { province }\end{array}$ & $\begin{array}{l}\text { Outside } \\
\text { concessions } \\
\text { area }\end{array}$ & $\begin{array}{l}\text { Within } \\
\text { concessions } \\
\text { area }\end{array}$ & $\begin{array}{l}\text { Oil Palm } \\
\text { concessions }\end{array}$ & $\begin{array}{l}\text { Logging } \\
\text { concessions }\end{array}$ & $\begin{array}{l}\text { Fiber } \\
\text { concessions }\end{array}$ & $\begin{array}{l}\text { Entire } \\
\text { province }\end{array}$ & $\begin{array}{l}\text { Outside } \\
\text { concessions } \\
\text { area }\end{array}$ & $\begin{array}{l}\text { Within } \\
\text { concessions } \\
\text { area }\end{array}$ & $\begin{array}{l}\text { Oil Palm } \\
\text { concessions }\end{array}$ & $\begin{array}{l}\text { Logging } \\
\text { concessions }\end{array}$ & $\begin{array}{l}\text { Fiber } \\
\text { concessions }\end{array}$ \\
\hline $\begin{array}{l}\text { Reference } \\
\text { number }\end{array}$ & Provinces & $C F I_{2000}(-)$ & & \multicolumn{10}{|c|}{ Change in $\mathrm{CFI}_{2000-2014}(\%)$} \\
\hline 32 & $\begin{array}{l}\text { Sumatera } \\
\text { Selatan }\end{array}$ & 0.35 & 0.34 & 0.37 & 0.38 & 0.28 & 0.37 & -3.11 & -0.08 & -18.50 & -15.30 & -3.52 & -20.05 \\
\hline 33 & $\begin{array}{l}\text { Sumatera } \\
\text { Utara }\end{array}$ & 0.24 & 0.25 & 0.18 & 0.30 & 0.12 & 0.21 & 18.20 & 18.70 & 12.58 & -11.71 & 57.23 & -2.79 \\
\hline 34 & $\begin{array}{l}\text { Yogyakarta } \\
\text { Indonesia }\end{array}$ & $\begin{array}{l}0.16 \\
0.21\end{array}$ & $\begin{array}{l}0.16 \\
0.21\end{array}$ & 0.19 & 0.26 & 0.09 & 0.22 & 23.76 & 21.83 & 44.27 & 27.22 & 109.40 & 96.49 \\
\hline
\end{tabular}




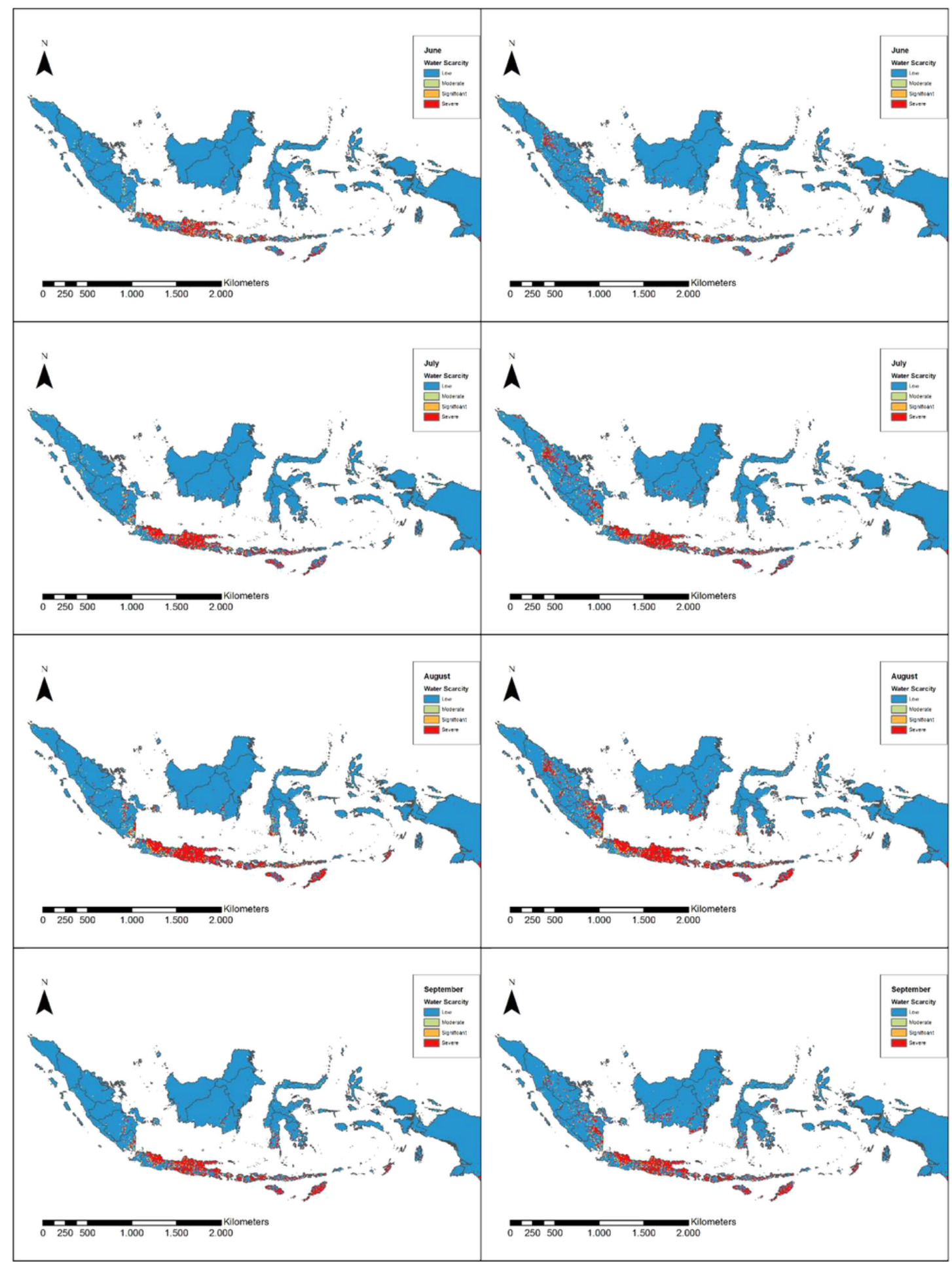

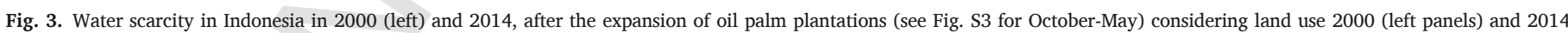
(right panels).

China, and Pakistan accounting for $40 \%$ of total imports. By importing $\mathrm{CPO}$ from Indonesia, these and other countries are virtually exporting a portion of their fertilizer pollution and greenhouse gas emissions to Indonesia (O'Bannon et al., 2014).

\section{Discussion}

\subsection{Multiple environmental impacts of oil palm production}

Economic globalization increases interdependencies among countries around the world, with remote policies and consumer behavior having localized socio-environmental impacts in producing developing 


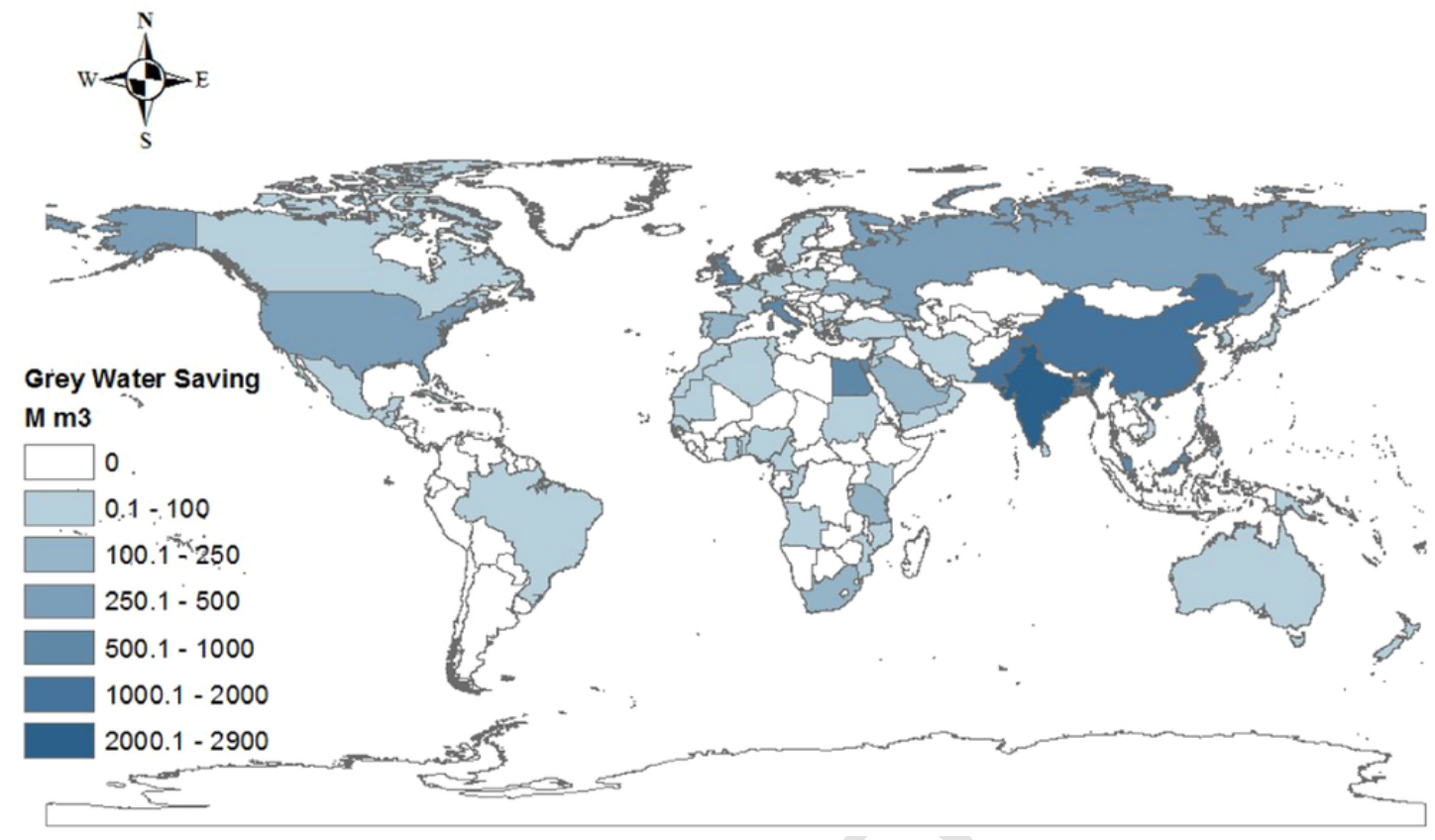

Fig. 4. Grey water saving by palm oil importer countries.

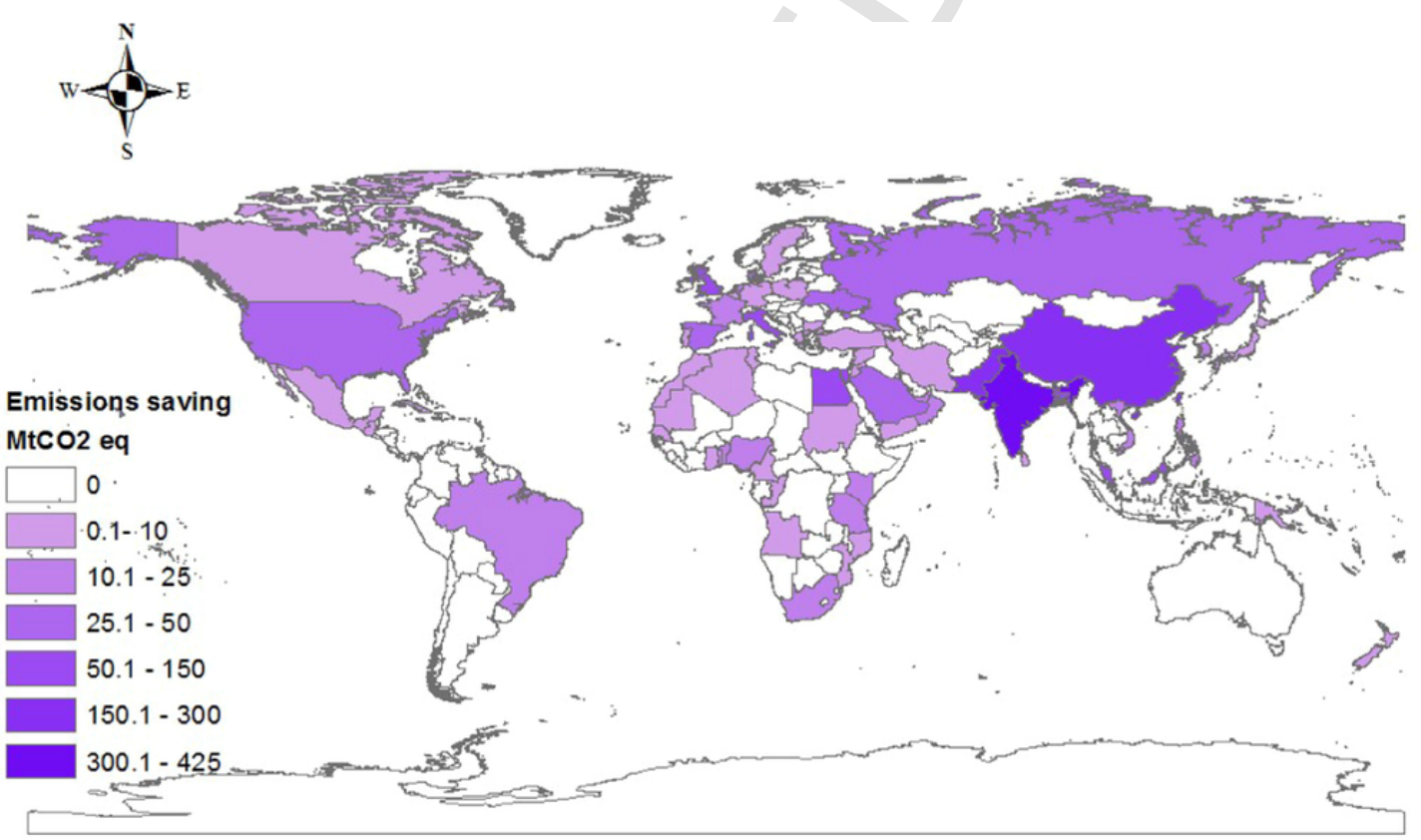

Fig. 5. CO2 emissions virtually induced by oil palm consumption in importer countries. These emissions are associated with land use change in Indonesia.

countries. Our estimate that four-fifths of Indonesia's palm oil production is exported clearly demonstrates how foreign dietary preferences and bioenergy demand have driven a rapid increase in palm oil production in Indonesia, thereby inducing substantial commercial agricultural expansion at the expense of native forests, natural habitats, and carbon storage capacity [18]. This analysis also shows that oil palm concessions are not only responsible for a substantial amount of the observed forest loss (as shown in previous studies) but that they also profoundly impact the local environment across multiple dimensions.

Indeed, this telecoupled expansion of oil palm production has produced complex and multiple socio-environmental impacts. Since the beginning of the century, we find that more than 20 Mha of forest has been lost in Indonesia, where 6 Mha took place within primary or in- tact forest (Margono et al., [84]). We also find that forest fragmentation increased by $58 \%$, an important contributor to habitat loss for wildlife species. These changes in land cover and land use are also associated with important carbon emissions and environmental pollution from fertilizer use. From a hydrological point of view, palm oil production has also intensified dry season water stress, as well as an expansion of the areas affected by seasonal water scarcity. This can locally compromise environmental flows, sustainable groundwater withdrawals, and other societal water uses. In Indonesia most of the rivers suffer from severe pollution, as water quality continues to decline ( FAO, 2012). Major sources of water pollution include fertilizer and pesticide runoff from agricultural lands and effluents from the processing 
of agricultural products (e.g. POME, palm oil mills effluent), the results of this study confirm.

In addition to local environmental impacts, oil palm production also has global effects associated with the $\mathrm{CO}_{2}$ emissions from land conversion (e.g., [15]. The current and anticipated impacts of all government-allocated leases on carbon emissions in the island of Kalimantan account for estimated net carbon emissions (with no peat burning) ranging between 0.54 and $1.89 \mathrm{Gt} \mathrm{CO}_{2}$ from 2000 to 2010 [18]. Our study adds to this work by determining the cumulative net carbon loss from oil palm plantations across the whole of Indonesia (2.43-4.37 Gt $\mathrm{CO}_{2 \mathrm{eq}}$ ). Land concessions for the production of oil palm are ultimately a response to: 1) fuel mandates by various governments intended to reduce carbon emissions and 2) shifting dietary preferences (particularly for populous developing nations like China, India, and Pakistan). This aspect of our study reinforces the fact that deforestation and peatland conversion to agriculture could largely eliminate the intended carbon savings of such climate change mitigation policies [49]. Biodiesel production from palm oil is often used as an example of displacement of land use associated with trade and environmental policies. Our work highlights these spillover effects where policies aimed at ensuring sustainable energy supplies have not realized absolute global reductions in emissions but instead have often served to simply shift the impacts of bioenergy production elsewhere.

\subsection{Displaced environmental impacts of food and energy demands}

Together, forest loss, habitat fragmentation, local exacerbation of water stress, enhancement of $\mathrm{CO}_{2}$ emissions, and pollution of freshwater resources due to oil palm production indicate the need for a more integrated approach to the development of sustainability and climate change mitigation policies as well as to personal consumer choices. Although oil palm expansion is driven in large part by demands from the food industry, the energy sector also plays an important role. Palm oil features several advantages compared to other vegetable oil sources making it a viable option for investors. These apparent advantages include the fact that it is a perennial crop with low management costs, that it is able to provide higher yields (up to ten times higher than rapeseed and soy [118]; [135]), and that is has relatively lower fertilizer, water and pesticide uses compared to other oil crops [86]. Moreover, biofuels appeal to governments as an (arguably) environmentally friendly renewable energy source that can be used as an alternative to fossil fuels. This perception of first-generation biofuels is what led to the EU's 2009 Renewable Energy Directive. This legislation inadvertantly contributed to oil palm expansion because of the mandatory increase of existing biofuel feedstocks at the expense of feedstuff and food security $[10 ; 12])$, leading to an increase of both prices and volatility of agricultural commodities $[27,126]$. Increasing energy demands along with the adoption of new "greener" policies are expected to have the effect of increasing palm oil production up to 256 million tonnes in 2050 [6] with consequent growing pressure on local environmental resources. This continuing growth in biofuel demand and dietary patterns is also driving the expansion of oil palm plantations in Latin America [54] and Africa (e.g., [113]; [103].

The rapid increase in the production and consumption of palm oil indicates a need for more strategic choices in where such plantations are located and how effectively they are utilized. For instance, local policies can aim to reduce forest degradation and land use change by increasing productivity in existing plantations (i.e. improving milling efficiency, increasing yields with biotechnology) and expanding oil palm plantations only to zones that have no forest cover and are not affected by land degradation [68]. Such efforts can be complemented by perspectives and management strategies that consider the full suite of potential environmental impacts from oil palm production including its effects on water availability and water quality $[74,90]$. In some places, more stringent criteria for qualifying biofuel sources have been put in place to minimize such negative impacts (e.g., EU's sustainability criteria, voluntary certification [28]). Yet despite the best efforts of policy makers to eliminate loop holes and environmental externalities, leakages can often occur where the undesired impact still takes place, though more indirectly. Such was the case during a recent two-year moratorium placed on Indonesian forest licenses, a measure intended to protect certain forest types from removal and conversion to oil palm [121]; [40]. The overall benefit was minimal as the types of forests not included in the deal experienced enhanced deforestation and conversion to oil palm plantations [40]; [84]. Furthermore, because four-fifths of oil palm production is exported (80.1\% of Indonesian palm oil in 2010 Food and Agriculture Organization of the United Nations [48]), the substantial environmental impacts of production essentially represents a virtual import of these effects by Indonesia and a form of unequal ecological exchange [117].

\section{Conclusion}

In a globalized world with growing interdependencies and distant socio-environmental connections, it is fundamental to recognize how decisions, policies, and consumption behaviors in one region of the world play out and have impacts on other areas. Minimizing negative distant impacts and favoring socio-environmental sustainability will require carefully integrated assessments that take into account the multiscalar and multidimensional nature of such telecouplings. This is especially true for palm oil production in Indonesia where roughly four-fifths of production is exported internationally. Our results show that the environmental impacts of this production have been substantial, enhancing forest loss $(-20 \%$ in concession areas since 2000$)$, forest fragmentation ( $+44 \%$ in concession areas since 2000), $\mathrm{CO}_{2}$ emissions (up to $4.37 \mathrm{Gt}$ $\mathrm{CO}_{2}$ ), and freshwater pollution (up to $18.3 \mathrm{~km}^{3}$ grey water). There therefore exists a clear trade-off for export-oriented oil palm production between apparent economic gain and substantial environmental degradation. For Indonesia and its palm oil trading partners, this includes not only considering the environmental impacts of a specific linkage between Indonesia and an individual country but also how changes to the environmental objectives of that country may indirectly affect the demand of other nations importing palm oil from Indonesia. Consumers should also be made aware of the environmental implications of products containing palm oil and the possibility to make more sustainable dietary and energy choices that minimize their distant, but no less real, impacts. In addition, policymakers have a responsibility to develop and implement strategies that carefully assess such teleconnecting potential. In order to avoid detrimental unexpected outcomes, it is fundamental to adopt integrated sustainability assessments that take into account the complexity associated with telecoupled systems. If the actors that have the capacity - either through the power of their markets or political influence - to affect these critical socio-environmental connections do not take an active role in shifting this process towards socio-environmental justice and sustainability, it is clear that economic globalization and ever-growing palm oil demand will only continue to reinforce a dynamic of unequal ecological exchange.

\section{Uncited references}

\section{Acknowledgements}

KFD was supported by Columbia University's Data Science Institute. We thank J. Miettinen for providing land cover maps and Janice Ser Huay Lee for data on carbon emissions. 


\section{Appendix A. Supporting information}

Supplementary data associated with this article can be found in the online version at doi:10.1016/j.rser.2018.12.050.

\section{References}

[1] S.A. Abood, J.S. Huay Lee, Z. Burivalova, J. Garcia-Ulloa, L.P. Koh, Relative contributions of the logging, fibre, oil palm and mining industries to forest loss in Indonesia, Conserv Lett 8 (2015) 58-67.

[2] W.M. Achten, L.V. Verchot, Implications of Biodiesel-Induced Land-Use Changes for $\mathrm{CO}_{2}$ Emissions: case Studies in Tropical America, Africa, and Southeast Asia, Ecol Soc 16 (2011) 14

[3] W. Anseeuw, L.A. Wily, L. Cotula, M. Taylor, Land rights and the rush for land: findings of the global commercial pressures on land research project ILC, Rome, 2012.

[4] M. Antonelli, G. Siciliano, M.E. Turvani, M.C. Rulli, Global investments in agricultural land and the role of the EU: drivers, scope and potential impacts, Land Use Policy 47 (2015) 98-111.

[5] A.G.S.J. Baccini, S.J. Goetz, W.S. Walker, N.T. Laporte, M. Sun, D. Sulla-Menashe, et al., Estimated carbon dioxide emissions from tropical deforestation improved by carbon-density maps, Nat Clim Change 2 (2012) 182-185.

[6] K. Bhaskar, G. Nagarajan, S. Sampath, Optimization of FOME (fish oil methyl esters) blend and EGR (exhaust gas recirculation) for simultaneous control of NOx and particulate matter emissions in diesel engines, Energy 62 (2013) 224-234.

[7] R. Biggs, S.R. Carpenter, W.A. Brock, Turning back from the brink: detecting an impending regime shift in time to avert it, Proc Natl Acad Sci USA 106 (2009) 826-831.

[8] BPS, (Badan Pusat Statistik) Statistics Indonesia Government of Indonesia, Jakarta, 2018, [Available at] 〈www.bps.go.id/〉.

[9] T. Breu, C. Bader, P. Messerli, A. Heinimann, S. Rist, S. Eckert, Large-scale land acquisition and its effects on the water balance in investor and host countries, PLoS One 11 (2016) e0150901.

[10] Bureau JC, Treguer D, Valin H. International implications of EU's biofuels policies. in: Proceedings of the international agricultural trade research consortium meeting, 2009, p. 12-14.

[11] F. Bulsink, A.Y. Hoekstra, M.J. Booij, The water footprint of Indonesian provinces related to the consumption of crop products, Hydr Earth Sys Sci 14 (2010) $119-128$.

[12] J.C. Bureau, J. Swinnen, EU policies and global food security, Glob Food Sec 16 (2017) 106-115.

[13] J. Busch, K. Ferretti-Gallon, J. Engelmann, M. Wright, K.G. Austin, F. Stolle, et al., Reductions in emissions from deforestation from Indonesia's moratorium on new oil palm, timber, and logging concessions, Proc Natl Acad Sci USA 112 (2015) 1328-1333.

[14] J. Busch, R.N. Lubowski, F. Godoy, M. Steininger, A.A. Yusuf, K. Austin, et al., Structuring economic incentives to reduce emissions from deforestation within Indonesia, Proc Natl Acad Sci USA 109 (2012) 1062-1067.

[15] R.A. Butler, L.P. Koh, J. Ghazoul, REDD in the red: palm oil could undermine carbon payment schemes, Cons Lett 2 (2009) 67-73.

[16] C.H. Cannon, D.R. Peart, M. Leighton, K. Kartawinata, The structure of lowland rainforest after selective logging in West Kalimantan, Indonesia, Ecol Manag 67 (1994) 49-68.

[17] M.A. Cairns, S. Brown, E.H. Helmer, G.A. Baumgardner, Root biomass allocation in the world's upland forests, Oecologia 111 (1997) 1-11.

[18] K.M. Carlson, L.M. Curran, D. Ratnasari, A.M. Pittman, B.S. Soares-Filho, G.P. Asner, et al., Committed carbon emissions, deforestation, and community land conversion from oil palm plantation expansion in West Kalimantan, Indonesia, Proc Natl Acad Sci USA 109 (2012) 7559-7564.

[19] K.M. Carlson, L.M. Curran, G.P. Asner, A.M. Pittman, S.N. Trigg, J. Marion Adeney, Carbon emissions from forest conversion by Kalimantan oil palm plantations, Nat Clim Change 3 (2013) 283-287.

[20] A.K. Chapagain, A.Y. Hoekstra, H.H.G. Savenije, R. Gautam, The water footprint of cotton consumption: an assessment of the impact of worldwide consumption of cotton products on the water resources in the cotton producing countries, Ecol Econ 60 (2006) 186-203.

[21] R.H.V. Corley, How much palm oil do we need?, Environ Sci Pol 12 (2009) 134-139.

[22] L. Cotula, The international political economy of the global land rush: a critical appraisal of trends, scale, geography and drivers, J Peas Stud 39 (2012) 649-680.

[23] C. Dalin, Y. Wada, T. Kastner, M.J. Puma, Groundwater depletion embedded in international food trade, Nature 543 (2017) 700-704.

[24] K.F. Davis, P. D’Odorico, M.C. Rulli, Land grabbing: a preliminary quantification of economic impacts on rural livelihoods, Popul Environ 36 (2014) 180-192.

[25] K.F. Davis, M.C. Rulli, P. D'Odorico, The global land rush and climate change, Earth'S Future 3 (2015) 298-311.

[26] K.F. Davis, K. Yu, M.C. Rulli, L. Pichdara, P. D’Odorico, Accelerated deforestation driven by large-scale land acquisitions in Cambodia, Nat Geosci 8 (2015) $772-775$.

[27] H. De Gorter, D. Drabik, D.R. Just, The economics of biofuel policies: impacts on price volatility in grain and oilseed markets Palgrave Macmillan, New York, 2015.

[28] R.S. DeFries, J. Fanzo, P. Mondal, R. Remans, S. Wood, Is voluntary certification
[29] J. Dell'Angelo, P. D'Odorico, M.C. Rulli, P. Marchand, The tragedy of the grabbed commons: coercion and dispossession in the global land rush, World Dev 92 (2017) 1-12.

[30] J. Dell'Angelo, P. D’Odorico, M.C. Rulli, Threats to sustainable development posed by land and water grabbing, Curr Opin Environ Sust 26 (2017) 120-128

[31] J. Dell'Angelo, M.C. Rulli, P. D'Odorico, The global water grabbing syndrome, Ecol Econ 143 (2018) 276-285.

[32] C. Dislich, A.C. Keyel, J. Salecker, Y. Kisel, K.M. Meyer, M. Auliya, et al., A review of the ecosystem functions in oil palm plantations, using forests as a reference system, Biol Rev 92 (2017) 1539-1569.

[33] P. D'Odorico, J.A. Carr, F. Laio, L. Ridolfi, S. Vandoni, Feeding humanity through global food trade, Earth'S Future 2 (2014) 458-469.

[34] P. D'Odorico, M.C. Rulli, J. Dell'Angelo, K.F. Davis, New frontiers of land and water commodification: socioenvironmental controversies of large-scale land acquisitions, Land Degrad Dev 28 (2017) 2234-2244.

[35] A. Dreher, N. Gaston, P. Martens, Measuring globalisation: gauging its consequences Springer, New York, 2008.

[36] H. Eakin, R. DeFries, S. Kerr, E.F. Lambin, J. Liu, P.J. Marcotullio, et al., Significance of telecoupling for exploration of land-use change, in: K.C. Seto, A. Reenberg (Eds.), Rethinking global land use in an urban era., MIT Press, Cambridge, 2014.

[37] M. Edelman, C. Oya, S.M. Borras Jr, Global land grabs: historical processes, theoretical and methodological implications and current trajectories, Third World Quar 34 (2013) 1517-1531.

[38] J. Liu, V. Hull, M. Batistella, R. DeFries, T. Dietz, F. Fu, et al., Framing sustainability in a telecoupled world, Ecol Soc 18 (2013) 26

[39] J. Liu, V. Hull, J. Luo, W. Yang, W. Liu, A. Viña, et al., Multiple telecouplings and their complex interrelationships, Ecol Soc 20 (2015) 44

[40] D.P. Edwards, L.P. Koh, W.F. Laurance, Indonesia's REDD + pact: saving imper illed forests or business as usual?, Biol Cons 151 (2012) 41-44.

[41] European Union. Directive 2003/30/EC of the European Parliament and of the Council of 8 May 2003 on the promotion of the use of biofuels or other renewable fuels for transport. Brussels: EU; 2003.

[42] European Union. Directive 2009/28/EC of the European Parliament and of the Council of 23 April 2009 on the promotion of the use of energy from renewable sources and amending and subsequently repealing Directives 2001/77/EC and 2003/30/EC. Brussels: EU; 2009.

[43] European Union. Proposal for a directive of the European Parliament and of the council amending Directive 98/70/EC relating to the quality of petrol and diesel fuels and amending Directive 2009/28/EC on the promotion of the use of energy from renewable sources. Brussles: EY; 2012.

[44] European Union, Energy: new target of 32\% from renewables by 2030 agreed by MEPs and ministers European Parliament News, Brussels, 2018.

[45] J. Fairhead, M. Leach, I. Scoones, Green grabbing: a new appropriation of nature?, J Peas Stud 39 (2012) 237-261.

[46] Food and Agriculture Organization of the United Nations, Cropwat 8.0 for windows FAO, Rome, 2009.

[47] FAO/IIASA/ISRIC/ISS-CAS/JRC, Harmonized world soil database (version 1.1) FAO, Rome/Laxenburg, 2009[/IIASA].

[48] Food and Agriculture Organization of the United Nations, FAOSTAT database FAO, Rome, 2018.

[49] J. Fargione, J. Hill, D. Tilman, S. Polasky, P. Hawthorne, Land clearing and the biofuel carbon debt, Science 319 (2008) 1235-1238.

[50] B.M. Fekete, C.J. Vörösmarty, W. Grabs, High-resolution fields of global runoff combining observed river discharge and simulated water balances, Glob Biogeochem Cycl 16 (2002) 15-1-15-10.

[51] C. Folke, S. Carpenter, B. Walker, M. Scheffer, T. Chapin, J. Rockström, Resilience thinking: integrating resilience, adaptability and transformability, Ecol Soc 15 (2010) 20.

[52] C. Folke, Å. Jansson, J. Rockström, P. Olsson, S.R. Carpenter, F. Stuart Chapin III et al., Reconnecting to the biosphere, AMBIO 40 (2011) 719-738.

[53] D.O. Fuller, M. Hardiono, E. Meijaard, Deforestation projections for carbon-rich peat swamp forests of Central Kalimantan, Indonesia, Environ Manag 48 (2011) 436-447.

[54] P.R. Furumo, T.M. Aide, Characterizing commercial oil palm expansion in Latin America: land use change and trade, Environ Res Lett 12 (2017) 024008.

[55] J.N. Galloway, F.J. Dentener, D.G. Capone, E.W. Boyer, R.W. Howarth, S.P. Seitzinger, et al., Nitrogen cycles: past, present, and future, Biogeochemistry 70 (2004) 153-226.

[56] D.L. Gaveau, D. Sheil, M.A. Salim, S. Arjasakusuma, M. Ancrenaz, P. Pacheco, E Meijaard, Rapid conversions and avoided deforestation: examining four decades of industrial plantation expansion in Borneo, Sci Rep 6 (2016) 32017.

[57] J. Germer, J. Sauerborn, Estimation of the impact of oil palm plantation establishment on greenhouse gas balance, Environ Dev Sust 10 (2008) 697-716.

[58] H. Gorter, D. Drabik, D.R. Just, E.M. Kliauga, The impact of OECD biofuels policies on developing countries, Agric Econ 44 (2013) 477-486.

[59] K.E. Green, W.M. Adams, Green grabbing and the dynamics of local-level engagement with neoliberalization in Tanzania's wildlife management areas, J Peas Stud 42 (2015) 97-117.

[60] P. Gunarso, M.E. Hartoyo, F. Agus, T.J. Killeen, Oil palm and land use change in Indonesia, Malaysia and Papua New Guinea, Reports from the technical panels of the 2nd greenhouse gas working group of the roundtable on sustainable palm oil (RSPO), Tropenbos International, Wageningen, 2013.

[61] M.C. Hansen, P.V. Potapov, R. Moore, M. Hancher, S. Turubanova, A. Tyukavina, et al., High-resolution global maps of 21st-century forest cover change, Science 342 (2013) 850-853.

[62] S. Henders, U.M. Persson, T. Kastner, Trading forests: land-use change and carbon emissions embodied in production and exports of forest-risk commodities, 
[64] A.Y. Hoekstra, M. Mekonnen, Global water scarcity: the monthly blue water footprint compared to blue water availability for the world's major river basins, PLoS One 7 (2011) e32688.

[65] A. Hooijer, M. Silvius, H. Wösten, S. Page, A. Hooijer, M. Silvius, et al., PEAT- $\mathrm{CO}_{2}$. Assessment of $\mathrm{CO}_{2}$ emissions from drained peatlands in SE Asia Delft Hydraulics, Delft, 2006.

[66] A. Hornborg, J.R. McNeill, J.M. Alier (Eds.), Rethinking environmental history: World-system history and global environmental change., Altamira Press, New York, 2007.

[67] K. Janda, L. Kristoufek, D. Zilberman, Biofuels: policies and impacts, Agric Econ 58 (2012) 372-386.

[68] R. Khatun, M.I.H. Reza, M. Moniruzzaman, Z. Yaakob, Sustainable oil palm in dustry: the possibilities, Renew Sust Energy Rev 76 (2017) 608-619.

[69] K. Kitayama, S.-I. Aiba, Ecosystem structure and productivity of tropical rain forests along altitudinal gradients with contrasting soil phosphorus pools on Mount Kinabalu, Borneo, J Ecol 90 (2002) 37-51.

[70] L.P. Koh, J. Miettinen, S.C. Liew, J. Ghazoul, Remotely sensed evidence of tropical peatland conversion to oil palm, Proc Natl Acad Sci USA 108 (2011) 5127-5132.

[71] International Fertilizer Industry Association, Assessment of fertilizer use by crop at the global level 2010-2010/11 IFA, Paris, 2013.

[72] E.F. Lambin, P. Meyfroidt, Global land use change, economic globalization, and the looming land scarcity, Proc Natl Acad Sci USA 108 (2011) 3465-3472.

[73] Y. Laumonier, A. Edin, M. Kanninen, A. Munandar, Landscape-scale variation in the structure and biomass of the hill dipterocarp forest of Sumatra: implications for carbon stock assessments, Ecol Manag 250 (2010) 505-513.

[74] R.K. Larsen, N. Jiwan, A. Rompas, J. Jenito, M. Osbeck, A. Tarigan, Towards 'hy brid accountability' in EU biofuels policy? Community grievances and competing water claims in the Central Kalimantan oil palm sector, Geoforum 54 (2014) 295-305.

[75] A. Lenschow, J. Newig, E. Challies, Globalization's limits to the environmental state? Integrating telecoupling into global environmental governance, Environ Polit 25 (2016) 136-159.

[76] ILC/CIRAD/CDE/GIGA/GIZ, The global land matrix observatory ILC, Rome, 2017, [Available at] 〈landmatrix.org〉.

[77] T.M. Li, To make live or let die? Rural dispossession and the protection of surplus populations, Antipode 41 (2010) 66-93.

[78] J. Liu, V. Hull, M. Batistella, R. DeFries, T. Dietz, F. Fu, et al., Framing sustainability in a telecoupled world, Ecol Soc 18 (2013) 26.

[79] M.S. Luskin, J.S. Brashares, K. Ickes, I.F. Sun, C. Fletcher, S.J. Wright, M.D. Potts, Cross-boundary subsidy cascades from oil palm degrade distant tropical forests, Nat Commun 8 (2017) 2231.

[80] G.K. MacDonald, K.A. Brauman, S. Sun, K.M. Carlson, E.S. Cassidy, J.S. Gerber, P.C. West, Rethinking agricultural trade relationships in an era of globalization, BioScience 65 (2015) 275-289.

[81] M. Maisarah Binti Salleh, Recovery of oil from palm oil mill effluent (POME) by solvent extraction [Doctoral dissertation] Universiti Teknologi Petronas, Malaysia, 2011.

[82] G. Manoli, A. Meijide, N. Huth, A. Knohl, Y. Kosugi, P. Burlando, et al., Ecohydrological changes after tropical forest conversion to oil palm, Environ Res Lett 13 (2018) 064035.

[83] P. Marchand, J.A. Carr, J. Dell'Angelo, M. Fader, J.A. Gephart, M. Kummu, et al., Reserves and trade jointly determine exposure to food supply shocks, Environ Res Lett 11 (2016) 095009.

[84] B.A. Margono, P.V. Potapov, S. Turubanova, F. Stolle, M.C. Hansen, Primary forest cover loss in Indonesia over 2000-2012, Nat Clim Change 4 (2014) 730-735.

[85] M.E. Margulis, N. McKeon, S.M. Borras Jr, Land grabbing and global governance: critical perspectives, Globalizations 10 (2013) 1-23.

[86] S. Mekhilef, S. Siga, R. Saidur, A review on palm oil biodiesel as a source of renewable fuel, Renew Sust Energy Rev 15 (2011) 1937-1949.

[87] M. Mekonnen, A.Y. Hoekstra, National water footprint accounts: the green, blue and grey water footprint of production and consumption UNESCO-IHE, Delft, 2011.

[88] M.M. Mekonnen, A.Y. Hoekstra, The green, blue and grey water footprint of crops and derived crop products, Hydrol Earth Sys Sci 15 (2011) 1577.

[89] M.M. Mekonnen, A.Y. Hoekstra, Four billion people facing severe water scarcity, Sci Adv 2 (2016) e1500323.

[90] J. Merten, A. Röll, T. Guillaume, A. Meijide, S. Tarigan, H. Agusta, et al., Water scarcity and oil palm expansion: social views and environmental processes, Ecol Soc 21 (2016) 5

[91] P. Messerli, A. Heinimann, M. Giger, T. Breu, O. Schönweger, From 'land grabbing' to sustainable investments in land: potential contributions by land change science, Curr Opin Environ Sust 5 (2013) 528-534.

[92] P. Meyfroidt, E.F. Lambin, K.H. Erb, T.W. Hertel, Globalization of land use: distant drivers of land change and geographic displacement of land use, Curr Opin Environ Sust 5 (2013) 438-444.

[93] J. Miettinen, C. Shi, W.J. Tan, S.C. Liew, 2010 land cover map of insular Southeast Asia in 250-m spatial resolution, Remote Sens Lett 2011 (3) (2011) 11-20.

[94] J. Miettinen, C. Shi, S.C. Liew, Land cover distribution in the peatlands of Peninsular Malaysia, Sumatra and Borneo in 2015 with changes since 1990, Glob Ecol Cons (2016)67-78.

[95] Ministry of Energy and Mineral Resources of Republic of Indonesia. Regulation 12/2 2015 015./http://ebtke.esdm.go.id/post/2017/03/07/1583/statistik.ebtke 2016?lang = en $>$

[96] Ministry of Trade of Republic of Indonesia. Data on Palm oil export; 2018. 〈http: //www.kemendag.go.id/en/economic-profile $\rangle$.

[97] MOE,Indonesia Ministry of Environment.
[99] R. Naylor, Expanding the boundaries of agricultural development, Food Secur 3 (2011) 233.

[100] C. Oberlack, S. Boillat, S. Brönnimann, J.D. Gerber, A. Heinimann, C. Ifejika Speranza, et al., Polycentric governance in telecoupled resource systems, Ecol Soc 23 (2018) 16.

[101] K. Obidzinski, R. Andriani, H. Komarudin, A. Andrianto, Environmental and social impacts of oil palm plantations and their implications for biofuel production in Indonesia, Ecol Soc 17 (2012) 25.

[102] D. Ojeda, Green pretexts: ecotourism, neoliberal conservation and land grabbing in Tayrona National Natural Park, Colombia, J Peas Stud 39 (2012) 357-375.

[103] E.M. Ordway, R.L. Naylor, R.N. Nkongho, E.F. Lambin, Oil palm expansion in Cameroon: insights into sustainability opportunities and challenges in Africa, Glob Environ Change 47 (2017) 190-200.

[104] M. Porkka, M. Kummu, S. Siebert, O. Varis, From food insufficiency towards trade dependency: a historical analysis of global food availability, Plos One 8 (2013) e82714.

[105] M. Porkka, J.H. Guillaume, S. Siebert, S. Schaphoff, M. Kummu, The use of food imports to overcome local limits to growth, Earth's Future 5 (2017) 393-407.

[106] B.D. Richter, M.M. Davis, C. Apse, C. Konrad, A presumptive standard for environmental flow protection, River Res Appl 28 (2012) 1312-1321.

[107] D.E. Rocheleau, Networked, rooted and territorial: green grabbing and resistance in Chiapas, J Peas Stud 42 (2015) 695-723.

[108] M.C. Rulli, D. Bellomi, A. Cazzoli, G. De Carolis, P. D’Odorico, The water-land-food nexus of first-generation biofuels, Sci Rep 6 (2016) 22521.

[109] M.C. Rulli, A. Saviori, P. D'Odorico, Global land and water grabbing, Proc Natl Acad Sci USA 110 (2013) 892-897.

[110] M.C. Rulli, M. Santini, D.T. Hayman, P. D’Odorico, The nexus between forest fragmentation in Africa and Ebola virus disease outbreaks, Sci Rep 7 (2017) 41613.

[111] M.C. Rulli, P. D'Odorico, The water footprint of land grabbing, Geophys Res Lett 40 (2013) 6130-6135.

[112] C. Runyan, P. D'Odorico, Global deforestation Cambridge University Press, London, 2016.

[113] J. Sayer, J. Ghazoul, P. Nelson, A.K. Boedhihartono, Oil palm expansion transforms tropical landscapes and livelihoods, Glob Food Secur 1 (2012) 114-119.

[114] A. Scheidel, A.H. Sorman, Energy transitions and the global land rush: ultimate drivers and persistent consequences, Glob Environ Change 22 (2012) 588-595.

[115] A. Scheidel, Carbon stock indicators: reductionist assessments and contentious policies on land use, J Peas Stud (2018) 1-22

[116] D. Seekell, J. Carr, J. Dell'Angelo, P. D'Odorico, M. Fader, J. Gephart, et al., Resilience in the global food system, Environ Res Lett 12 (2017) 025010.

[117] J.M. Shandra, E. Shor, B. London, World polity, unequal ecological exchange, and organic water pollution: a cross-national analysis of developing nations, $\mathrm{Hu}$ man Ecol Rev 16 (2009) 53-63.

[118] E.G. Shay, Diesel fuel from vegetable oils: status and opportunities, BiomassBioenergy 4 (1993) 227-242.

[119] G. Siciliano, M.C. Rulli, P. D'Odorico, European large-scale farmland investments and the land-water-energy-food nexus, Adv Water Resour 110 (2017) 579-590.

[120] J.W.F. Slik, S.-I. Aiba, F.Q. Brearley, C.H. Cannon, O. Forshed, K. Kitayama, et al., Environmental correlates of tree biomass, basal area, wood specific gravity and stem density gradients in Borneo's tropical forests, Glob Ecol Biogeogr 19 (2010) 50-60.

[121] S. Sloan, Indonesia's moratorium on new forest licenses: an update, Land Use Pol 38 (2014) 37-40.

[122] U.S. Energy Independence and Security Act of 2007 (Pub.L. 110-140); 2007.

[123] UNCTAD. In: Proceedings of the United Nations conference on trade and development; 2012. Available at 〈unctad.org/en/Pages/Home.aspx〉.

[124] USDA-Global Agricultural Information Network. Indonesia Biofuels Annual Report 2017. GAIN Report Number: ID1714. 〈https://gain.fas.usda.gov/ Recent\%20GAIN\%20Publications/Biofuels\%20Annual_Jakarta_Indonesia 6-20-2017.pdf $\rangle ; 2017$.

[125] USDA-Global Agricultural Information Network. Indonesia Oilseeds and Products Update July 2018. GAIN Report Number: ID1821. 〈https://gain.fas.usda.gov/ Recent $\% 20$ GAIN\%20Publications/Oilseeds\%20and\%20Products\%20Update_ Jakarta_Indonesia_7-27-2018.pdf); 2018.

[126] H. Valin, D. Peters, M. van den Berg, S. Frank, P. Havlik, N. Forsell, et al., The land use change impact of biofuels consumed in the EU: quantification of area and greenhouse gas impacts European Commission, Brussels, 2015.

[127] M. Van Noordwijk, N.M. Khasanah, S. Dewi, Can intensification reduce emission intensity of biofuel through optimized fertilizer use? Theory and the case of oil palm in Indonesia, Glob Change Biol Bioenergy 9 (2017) 940-952.

[128] P. Vogt, K.H. Riitters, C. Estreguil, J. Kozak, T.G. Wade, J.D. Wickham, Mapping spatial patterns with morphological image processing, Landsc Ecol 22 (2007) 171-177.

[129] H.R. Von Uexkull, T.H. Fairhurst, The oil palm: fertilizing for high yield and quality International Potash Institute, Zürich, 1991.

[130] M. Warren, K. Hergoualc'h, J.B. Kauffman, D. Murdiyarso, R. Kolka, An appraisal of Indonesia's immense peat carbon stock using national peatland maps: uncertainties and potential losses from conversion, Carbon Balance Manag 12 (2017) 12.

[131] B. White, A. Dasgupta, Agrofuels capitalism: a view from political economy, J Peas Stud 37 (2010) 593-607.

[132] B. White, S.M. Borras Jr, R. Hall, I. Scoones, W. Wolford, The new enclosures:

[133] critical perspectives on corporate land deals, J Peas Stud 39 (2012) 619-647. 
[134] L. Wottiez, S. Turhina, D. Deccy, M. Slingerland, M. Van Noordwlik, K. Giller, Fertilizer application practices and nutrient deficiencies in smallholder oil palm plantations in Indonesia, Exp Agric (2018) 1-17.

[135] W. Yan, A makeover for the world's most hated crop, Nature 543 (2017) 306-308.
[136] O.R. Young, F. Berkhout, G.C. Gallopin, M.A. Janssen, E. Ostrom, Van, S. der Leeuw, The globalization of socio-ecological systems: an agenda for scientific research, Glob Environ Change 16 (2006) 304-316.

[137] A. Zoomers, Globalisation and the foreignisation of space: seven processes driving the current global land grab, J Peas Stud 37 (2010) 429-447. 